\title{
SENSORY, CHEMICAL AND BIOLOGICAL EVALUATION OF SOME PRODUCTS FORTIFIED BY WHOLE FLAXSEED
}

\author{
AHMED, M. GAAFAR ${ }^{1}$, E. A. HEADER ${ }^{2}$, FATMA. A. EL-SHERIF ${ }^{2}$, \\ M. S. EL-DASHLOUTY2 ${ }^{2}$ AND S. A. EL-BROLLOSE ${ }^{2}$
}

1. Special Food and Nutrition dept. Food Tech. Res. Ins., ARC, Giza

2. Nutrition and Food Science Dept. Faculty of Home Economics, Minufiya University

(Manuscript received 16 December 2010)

\begin{abstract}
The purpose of this study was to develop a mainstream food item using whole flaxseed and test the consumer acceptability, chemical and biological evaluation of the products. Chemical composition of flaxseed showed that contents of moisture was $(7.06 \%)$, protein $(24.87 \%)$, fat $(39.64 \%)$, crude fiber $(8.74 \%)$, ash $(3.51 \%)$ and total carbohydrate (23.19 \%). Flaxseed oil was have high content of unsaturated fatty acids. oleic acid (17.11\%), linoleic acid (15.56\%) and linolenic acid (58.68\%). Sensory evaluation of (pan bread-pizza-Tahina) showed that all were acceptable of eating qualities. Also, results showed that addition of flaxseed to wheat flour by $15 \%$ increased the protein content, fat, fiber, and ash. Meanwhile, the content of carbohydrates was decreased in the bread and pizza. Carbohydrates increased and fat decreased for Tahina $50 \%$ flaxseed. Data indicated that feed efficiency ratio of rats fed on diets containing flaxseed products were higher than rats fed on diets without flaxseed and results indicated also that, the diets containing flaxseed decreased concentration of serum total cholesterol compared to diet with no flaxseed. Flaxseed diet increased the level of serum HDL-C while serum LDL-C and VLDL-C significantly decreased.

Key word: Flaxseed, Chemical composition, Flaxseed oil, Pan Bread, Pizza, Tahina, Biological Evaluation.
\end{abstract}

\section{INTRODUCTION}

Flaxseed (Linum unisatissimum) has a history of food use in Europe and Asia. In the US, until the early 1990s flaxseed had been incorporated at low levels in some brands of cereal, bread, and other bakery products. However, during the past decade, potential health benefits associated with consumption of flaxseed and flaxseed meal have become more prominent. These potential health benefits include anticancer effects, antiviral and antibactericidal activity, anti-inflammatory effect, ion reduction, laxative uses, and reduction of atherogenic risks (Jenkins et al., 1999, Yamashita et al., (2003).

Flaxseed food products have been found with increasing frequency in supermarkets and health food stores all over the some country. Increased consumption of flaxseed products by everyone, including pregnant women, is anticipated due to these potential health benefits. The major constituents of flaxseed 
are oil (36\%), protein (24\%), and fiber (32\%). Historically, flaxseed has been prized for its oil, called linseed oil, which is used in industrial applications. Most of the protein is concentrated in flaxseed meal, a by-product of the flaxseed- crushing industry (Arafat et al.,2008). Flaxseed is one of the richest plant sources of the $n-3$ fatty acid, a-linolenic acid (ALA), and the richest source of secoisolariciresinol diglycoside (SDG). SDG, a lignan precursor, is converted by the bacterial flora of the human colon to two major mammalian lignans, enterodiol and enterolactone, found in the biological fluids of humans and animals (Sylvie Dodin ET AL., 2008).

Thus, this study aimed to throw light on the chemical composition of flaxseed as well as to process some untraditional new foods from these seeds which may be prepared under home conditions or commercially such as (bakery and other oilseeds products), also this study includes investigation of biological effects of flaxseed on hypercholesterolemic rats.

\section{MATERIALS AND METHODS}

\subsection{Materials}

Flaxseeds (2007 year of production) were obtained from Agricultural Research Center, Oil Crops Department, Giza, Egypt. Wheat flour (82\%), corn oil, eggs, salt, sugar, instant dry yeast, green pepper, tomato, mozzarella cheese, black olive, tomato sauce, ground black pepper and sesame seeds were obtained from the local market of Shibin El-Kom, Minufiya.

\subsection{Methods}

2.2.1. Chemical analysis:- The contents of moisture, crude oil, crude protein ( $\mathrm{N} x$ 6.25), crude fiber and total ash of flaxseed and their products were determined as described in A.O.A.C. (2000). The carbohydrate content was calculated by difference.

2.2.2. Fatty acid composition:- The methyl esters of crude oil were prepared according to Chalvardjian (1964), using $1 \%$ of $\mathrm{H} 2 \mathrm{SO} 4$ in absolute methyl alcohol. A Perkin-Elmer gas chromatography (Model F22) with a flame ionization detector was used in the presence of nitrogen as a carrier gas. A glass column ( $2 \mathrm{~m} \times 2.5 \mathrm{~mm})$ packed with Chrom Q $80 / 100$ mesh at a temperature of $270^{\circ} \mathrm{C}$ was used. Standard fatty acids methyl esters were used for identification. The area under each peak was measured and the precentage expressed in regard to the total area.

\subsubsection{Technological methods}

2.2.2.1. Preparation of flaxseeds:- The seeds were dry cleaned to remove dust and undesirable materials. After cleaning, the seeds were roasted at $150^{\circ} \mathrm{C}$ for $15 \mathrm{~min}$ in an electric oven. Then the seeds were grounded and kept stored at $4^{\circ} \mathrm{C}$ until used. 
2.2.2.2. Preparation of sesame seeds;- Sesame seeds were cleaned to remove dust and undesirable materials, washed with tap water, the seeds were toasted in an electric oven for 3 hours at $150^{\circ} \mathrm{C}$. Finally, the toasted sesame were grind in an electric grinding mill until Tahina produced.

2.2.2.3. Preparation of some bakery products:- Flaxseeds powders were added to wheat flour (82 extraction) for making products, the different ingredients used in preparation pizza and toast bread are shown in table (1), provided that several formulae were tested and the best one presented.

2.2. 2.1. Pan bread preparation:- Pan bread prepared according to the formula shown in the table (1). The flour $82 \%$ (fortified with 10,15 and $20 \%$ flaxseed powder) added to sugar, salt and yeast then mixed together by hand to form homogeneous mass. The mixing was continued until the dough had as smooth texture (mixing time was $10 \mathrm{~min}$ ). Dough was left to ferment for $30 \mathrm{~min}$ then put in oblongtray and left for arrest period of $15 \mathrm{~min}$. Then dough baked in gas oven at $220^{\circ} \mathrm{C}$ for $30 \mathrm{~min}$.

2.2.3.2. Pizza preparation:- Pizza is prepared as home made method, using the wheat flour (72\%). Flaxseeds powder was added at the percentages of 10,15 and $100 \%$ on the account of flour, oil and eggs are added with yeast and sugar, finally little salt and water were incorporated to holding dough. The dough is formed, left to ferment for 30 minute, and then cut into round pieces. Slices of tomato, cheese, green pepper, tomato sauce with little from milled black pepper and black olive formed the cover of surface. The covered dough disc was then baked at $225^{\circ} \mathrm{C}$ for $30 \mathrm{~min}$ in gas oven.

4.2. 2.3. Tahina preparation:- Tahina is pressed from sesame seeds. There are two types of Tahina, red and white according to colour and kind of used sesame (Saba, 1991). Toasted sesame seeds and toasted flaxseeds were mixed at the percentages 25, 50, 75 and $100 \%$, then ground in an electric mill until Tahina formed.

\subsubsection{Sensory evaluation}

\subsubsection{Pan bread}

The sensory evaluation of the produced pan bread including:- Pan bread was organoleptically evaluated for appearance, crust colour, crumb colour, crumb texture, taste, and odour. A hedonic scale of 1 to 7 was used, $1=$ poor and $7=$ excellent according to the methods described by Gaafar (2005).

2.2.3.2. Pizza:- Sensory evaluation of control and experimental samples of pizza was carried out by aid of 10 panalists in the Faculty of Home Economics, Minufiya University for: 1) texture, 2) aroma, 3) taste, 4) colour and 5) overall acceptability using hedonic scale as follows: 1 to 7 was used, $1=$ poor and $7=$ excellent 


\subsubsection{Biological experiments}

2.2.4.1. Animals:- Forty-eight male albino rats of Sprague Dawley strain weighting $(110.122 \mathrm{~g})$ distributed on 8 groups (6 rats each). All rats were housed in well aerated cages under hygienic condition, and fed on basal diet for one week for adaptation in the Animal House of Food Technology Research, Institute, Agricultural Research Center, Giza, from which also the rats were obtained.

2.2.4.2. Basal diet:- The basal diet (Campbell, 1963) consisted of (12\%) casein (protein source), $(10 \%)$ corn oil, $(0.25 \%)$ choline chloride, $(1.0 \%)$ vitamin mixture, $(4.0 \%)$ salt mixture, $(5.0 \%)$ cellulose, $(10 \%)$ sucrose, and the remainder is corn starch $(57.75 \%)$.

2.2.4.3. Experimental design:- After feeding on the basal diet, rats were divided into 2 main groups. The first main group: (6 rats) fed on basal diet as control negative (control). The second main group: (42 rats) fed on hypercholesterolemic diet for 2 weeks (basal diet supplemented with $1 \%$ cholesterol $+10 \%$ sheep tail fat $+0.25 \%$ cholic acid). The later main group was then divided into 7 groups (6 rats each). The first group was feed on the hypercholesterolemic diet for 4 weeks and considered as positive control group. The second (group 2) and third (group 3) were fed on dried bread control and dried bread with 15\% flaxseed meal. The fourth (group 4) and fifth (group 5) were fed on dried Margarita pizza and dried Margarita pizza with 15\% flaxseed meal. The sixth (group 6) and seventh (group 7) were fed on Tahina (100\% sesame) and Tahina with $50 \%$ flaxseed.

\subsubsection{Biochemical analysis}

4.2.5.1. Determination of lipid profile:- Total cholesterol, Serum tricylglyceride, Total lipids High density lipoprotein (HDL) in the plasma were determined according to the method of (Allain and Poon, 1974), Fredrickson et al., (1967), Toro and Ackerman (1975) and Burstein (1970) by a quantitative enzymatic colorimetric method using standard kit.

Low density lipoprotein cholesterol (LDL-cholesterol) was calculated according to the method of Lee and Nieman (1996) using the following formulae:

$$
\begin{gathered}
\text { VLDL }=\mathrm{TG} / 5 \\
\mathrm{LDL}=\mathrm{TC}-(\mathrm{VLDL}+\mathrm{HDL})
\end{gathered}
$$

2.6. Statistically analyzed:- Data were statistically analyzed according to Snedecor and Cocheran (1980). 


\section{RESULTS AND DISCUSSION}

\subsection{Chemical composition of whole flaxseed}

Data presented in table (1) show the chemical composition of flaxseed on dry weight basis. It could be noticed that the whole flaxseed is rich in fat, protein and fiber. The moisture content of whole flaxseed was $7.06 \%$. Meanwhile, the protein content was $24.87 \%$, the fat content $39.69 \%$, crude fiber $8.74 \%$, ash $3.51 \%$ and total carbohydrate $23.19 \%$, respectively. In this respect, EL-kady, Eman (1995) determined the chemical composition of linseed, and found that, the moisture, fat, protein, crude fibers and ash were 5.12, 39.19, 21.17, 4.86 and 5.50\%, respectively. This finding may focus the interest of utilizing flax as a high protein source in some food formulation. Generally, the value of fat content was higher than those reported by Mahgoob, Magda (2008) and slightly lower than that reported by Arafat et al., (2008).

Table 1. Chemical composition of whole flaxseed (on dry weight basis).

\begin{tabular}{|l|c|}
\hline Components & $\%$ \\
\hline Moisture & $7.06 \pm 1.01$ \\
\hline Oils & $39.69 \pm 2.14$ \\
\hline Protein & $24.87 \pm 1.54$ \\
\hline Carbohydrates & $23.19 \pm 2.35$ \\
\hline Ash & $3.51 \pm 0.26$ \\
\hline Fiber & $8.74 \pm 0.57$ \\
\hline
\end{tabular}

\subsection{Fatty acids composition of flaxseed oils}

The fatty acids composition of flaxseed oil was investigated by gas liquid chromatography technique. The results obtained are tabulated in table (2). It could be observed that flaxseed oil was found to have high content of unsaturated fatty acids. From the obtained results it could be observed that the major fatty acids in flaxseed oil were linolenic acid C18:3 (58.68\%), linoleic acid C18:2 (15.56\%) and oleic acid C18:1 (17.11\%). The fatty acid composition of flaxseed oil indicated that flaxseed oil rich in essential fatty acids, in particular the omega- 3 fatty acids, and may replace sesame oil in Tahina making. Harper et al., (2006) found that, the fatty acids composition in flaxseed oil were C18:3 (58.9\%), C18:2 (17.9\%), C18:1 (16.9\%), C16:0 (6.91\%) and C18:0 (3.90\%), respectively. 
Table 2. Fatty acids composition of flaxseed oils (\%).

\begin{tabular}{|l|c|}
\hline \multicolumn{1}{|c|}{ Fatty acids } & $\%$ \\
\hline Palmitoliec acid $\mathrm{C}_{14: 0}$ & 0.16 \\
\hline Palmitic acid $\mathrm{C}_{16: 0}$ & 5.43 \\
\hline Stearic acid $\mathrm{C}_{18: 0}$ & 3.06 \\
\hline Oleic acid $\mathrm{C}_{18: 1}$ & 17.11 \\
\hline linoleic acid $\mathrm{C}_{18: 2}$ & 15.56 \\
\hline linolenic acid $\mathrm{C}_{18: 3}$ & 58.68 \\
\hline Total saturated & 8.65 \\
\hline Monounsaturated & 17.11 \\
\hline Polyunsaturated & 74.24 \\
\hline Total unsaturated & 91.35 \\
\hline
\end{tabular}

\subsection{Sensory evaluation of products made from different levels of flaxseed replacement}

\subsubsection{Sensory evaluation of pan bread}

The results concerning sensory evaluation of pan bread produced from different levels of flaxseed used are shown in table (3). It could be noticed from table (6) that pan bread samples made from $100 \%$ wheat flour was characterized with high acceptability for all parameters $(6.56,6.62,6.54,6.42,6.80$, and 6.94) with total score 39.88. However, from the same table (6) flaxseed used instead of wheat flour up to $15 \%$ gave somewhat similar scores provided that crumb grain score was very slightly less compared to the control sample. Therefore, from the above result it can be concluded that pan bread substitute samples 10 and $15 \%$ instead of wheat are suitable for using. Generally, these data agree well with Afaik and Munir (2007) who indicated that the sensory properties showed that an acceptable bread could be produced using flaxseed flour up to a level of $200 \mathrm{~g} / \mathrm{kg}(20 \%)$.

Table 3. Sensory evaluation of fortified pan bread with flaxseed.

\begin{tabular}{|l|c|c|c|c|}
\hline \multirow{2}{*}{ Parameters } & \multirow{2}{*}{ control } & \multicolumn{3}{|c|}{ pan bread with Flaxseed (\%) } \\
\cline { 3 - 5 } & & 10 & 15 & 20 \\
\hline Appearance & $6.56 \pm 0.52^{\mathrm{a}}$ & $6.31 \pm 0.46^{\mathrm{a}}$ & $6.16 \pm 0.35^{\mathrm{a}}$ & $5.34 \pm 0.53^{\mathrm{b}}$ \\
\hline Crumb texture & $6.62 \pm 0.63^{\mathrm{a}}$ & $6.54 \pm 0.39^{\mathrm{a}}$ & $6.26 \pm 0.48^{\mathrm{a}}$ & $4.75 \pm 0.36^{\mathrm{b}}$ \\
\hline Crumb grain & $6.54 \pm 0.43^{\mathrm{a}}$ & $6.02 \pm 0.48^{\mathrm{a}}$ & $5.88 \pm 0.45^{\mathrm{a}}$ & $4.75 \pm 0.40^{\mathrm{b}}$ \\
\hline Crust colour & $6.42 \pm 0.51^{\mathrm{a}}$ & $6.40 \pm 0.55^{\mathrm{a}}$ & $6.21 \pm 0.42^{\mathrm{ab}}$ & $5.32 \pm 0.28^{\mathrm{b}}$ \\
\hline Taste & $6.8 \pm 0.60^{\mathrm{a}}$ & $6.24 \pm 0.37^{\mathrm{a}}$ & $6.00 \pm 0.52^{\mathrm{ab}}$ & $5.45 \pm 0.39^{\mathrm{b}}$ \\
\hline Odour & $6.94 \pm 0.54^{\mathrm{a}}$ & $6.52 \pm 0.61^{\mathrm{a}}$ & $6.16 \pm 0.48^{\mathrm{a}}$ & $4.63 \pm 0.31^{\mathrm{b}}$ \\
\hline Total score & $39.88 \pm 1.23^{\mathrm{a}}$ & $38.03 \pm 1.08^{\mathrm{a}}$ & $36.67 \pm 1.45^{\mathrm{ab}}$ & $30.25 \pm 1.05^{\mathrm{b}}$ \\
\hline
\end{tabular}

Means in the same raw with different letters are significantly different $(P \leq 0.05)$. 


\subsubsection{Sensory evaluation of pizza}

Table (4) represent sensory properties mean scores of pizza containing flaxseed at different levels of replacement. From this table it could be noticed that pizza made by $20 \%$ flaxseed replacement was decreased in all parameters tested (texture, aroma, taste, colour and overall acceptability) with total score of 38.7, being less when compared with control group (45.4), but was still acceptable (sample rated very good to good for different parameters). From the results of same table it could be noticed that pizza made at 10 and $15 \%$ flaxseed replacement gave more or similar less scores when compared with control (with total score $44.6,43.8 \%$ and $45.4 \%$, respectively). Montesano et al., (2002) reported that, when samples covered with the toppings of pizza (sauce and cheese), the consumers could not detect a difference in the crust made with high gluten flour and high gluten flour with flaxseed.

Table 4. Sensory evaluation of fortified pizza with flaxseed.

\begin{tabular}{|l|c|c|c|c|}
\hline \multirow{2}{*}{ Parameters } & \multirow{2}{*}{ control } & \multicolumn{3}{|c|}{ pizza with Flaxseed (\%) } \\
\cline { 3 - 5 } & & 10 & 15 & 20 \\
\hline Texture & $8.9 \pm 0.68^{\mathrm{a}}$ & $8.5 \pm 0.76^{\mathrm{ab}}$ & $8.3 \pm 0.44^{\mathrm{ab}}$ & $7.1 \pm 0.43^{\mathrm{b}}$ \\
\hline Aroma & $9.3 \pm 0.73^{\mathrm{a}}$ & $9.0 \pm 0.84^{\mathrm{a}}$ & $8.8 \pm 0.67^{\mathrm{a}}$ & $7.2 \pm 0.58^{\mathrm{b}}$ \\
\hline Taste & $9.2 \pm 0.65^{\mathrm{a}}$ & $9.1 \pm 0.57^{\mathrm{a}}$ & $8.9 \pm 0.53^{\mathrm{a}}$ & $7.9 \pm 0.60^{\mathrm{b}}$ \\
\hline Colour & $8.9 \pm 0.71^{\mathrm{a}}$ & $9.0 \pm 0.64^{\mathrm{a}}$ & $8.9 \pm 0.65^{\mathrm{a}}$ & $8.3 \pm 0.54^{\mathrm{b}}$ \\
\hline Overall acceptability & $9.1 \pm 0.66^{\mathrm{a}}$ & $9.0 \pm 0.74^{\mathrm{a}}$ & $8.9 \pm 0.64^{\mathrm{a}}$ & $8.2 \pm 0.66^{\mathrm{b}}$ \\
\hline Total score & $45.4 \pm 1.57^{\mathrm{a}}$ & $44.6 \pm 2.33^{\mathrm{a}}$ & $43.8 \pm 1.86^{\mathrm{a}}$ & $38.7 \pm 2.54^{\mathrm{b}}$ \\
\hline
\end{tabular}

Means in the same raw with different letters are significantly different $(P \leq 0.05)$.

\subsubsection{Sensory evaluation of Tahina}

Average scores concerning sensory evaluation of Tahina produced from different seeds (sesame and flaxseed) are shown in table (5). It could be noticed from table (8) that Tahina sample made from $100 \%$ flaxseed was characterized with low acceptability according to taste, colour, texture, odour and overall acceptability with total score $24.2 \%$. However, from the same table (8) flaxseed used instead of sesame seed up to $50 \%$ gave somewhat similar scores compared to the control. It is of great importance to conclude from the obtained results that flaxseed can be used instead of sesame seeds up to $50 \%$ in the making of Tahina substitute samples. Therefore, it is evident that Tahina substitution at 25 and $50 \%$ of sesame seeds are suitable for use, while samples made with 75 and $100 \%$ could not be recommended because lowest average scores. 
Table 5. Sensory evaluation of fortified Tahina with flaxseed.

\begin{tabular}{|l|c|c|c|c|c|}
\hline \multirow{2}{*}{ Parameters } & \multirow{2}{*}{ control } & \multicolumn{4}{|c|}{ Tahina with Flaxseed (\%) } \\
\cline { 3 - 6 } & & 25 & 50 & 75 & 100 \\
\hline Taste & $9.0 \pm 0.45^{\mathrm{a}}$ & $8.7 \pm 0.38^{\mathrm{a}}$ & $8.1 \pm 0.35^{\mathrm{b}}$ & $6.8 \pm 0.49^{\mathrm{bc}}$ & $5.5 \pm 0.44^{\mathrm{c}}$ \\
\hline Colour & $9.8 \pm 0.43^{\mathrm{a}}$ & $9.3 \pm 0.45^{\mathrm{ab}}$ & $8.3 \pm 0.52^{\mathrm{b}}$ & $5.8 \pm 0.39^{\mathrm{bc}}$ & $3.3 \pm 0.25^{\mathrm{c}}$ \\
\hline Texture & $9.5 \pm 0.25^{\mathrm{a}}$ & $9.1 \pm 0.39^{\mathrm{a}}$ & $8.5 \pm 0.67^{\mathrm{ab}}$ & $7.0 \pm 0.53^{\mathrm{b}}$ & $5.5 \pm 0.36^{\mathrm{c}}$ \\
\hline Odour & $9.0 \pm 0.40^{\mathrm{a}}$ & $9.2 \pm 0.47^{\mathrm{a}}$ & $9.1 \pm 0.59^{\mathrm{ab}}$ & $6.3 \pm 0.51^{\mathrm{b}}$ & $5.8 \pm 0.44^{\mathrm{c}}$ \\
\hline Overall acceptability & $9.3 \pm 0.48^{\mathrm{a}}$ & $9.3 \pm 0.36^{\mathrm{a}}$ & $8.7 \pm 0.61^{\mathrm{ab}}$ & $6.2 \pm 0.45^{\mathrm{b}}$ & $4.2 \pm 0.42^{\mathrm{c}}$ \\
\hline Total score & $46.6 \pm 1.54^{\mathrm{a}}$ & $45.6 \pm 1.36^{\mathrm{a}}$ & $42.7 \pm 2.24^{\mathrm{ab}}$ & $32.1 \pm 2.35^{\mathrm{b}}$ & $24.2 \pm 3.20^{\mathrm{c}}$ \\
\hline
\end{tabular}

Means in the same raw with different letters are significantly different $(P \leq 0.05)$.

\subsection{Chemical composition of the best products fortified with flaxseed}

\subsubsection{Pan bread}

The changes in chemical composition of bread fortified with flaxseed at the level of $15 \%$ shown in table (6). Addition of flaxseed to wheat flour by $15 \%$ increased the protein content, fat, fiber and ash. Meanwhile, the content of carbohydrates was decreased in the bread substituted with $15 \%$ flaxseed. These results in accordance with the results of Pohjanheimo et al., (2006) who showed that, analysis of chemical composition indicated that the flaxseed bread samples contained higher protein, fat, crude fibre and ash. This study has shown also that acceptable bread of higher nutritional value can be produced from linseed. Moreover, indicated that, the flaxseed rolls retained moisture and softness more efficiently than the control rolls that do not contain flaxseed. The flaxseed rolls were also high in fiber. Therefore, from a nutritional viewpoint flaxseed shows beneficial properties in bread making.

\subsubsection{Pizza}

The changes in chemical composition of pizza fortified with flaxseed at the level of $15 \%$ are shown in table (6). Addition of flaxseed to pizza at $15 \%$ level increased the protein content, fiber, fat and ash. The content of carbohydrates, however, was decreased in pizza fortified by $15 \%$ flaxseed. Gaafar (2005) reported that, the addition of hulled flaxseed (HF) and defatted flaxseed flour (FF) to cakes significantly increased all-chemical composition except the total carbohydrates.

\subsubsection{Tahina}

The chemical analysis in table (6) indicated some variations concerning the chemical composition of Tahina sesame (control) and Tahina substituted with 50\% flaxseed. Addition of flaxseed to sesame seed to make Tahina increased the content of protein, fiber and total carbohydrates but, decreased ash and fat contents in Tahina made with $50 \%$ flaxseed. However, from above mentioned data it could be observed that there variation was not high between the chemical analysis of flaxseed Tahina 
and sesame Tahina. Therefore, the flaxseed Tahina may replace the sesame Tahina as a source of fat, protein and carbohydrates in salad and Halawa Tahiniya making.

Table 6. Effect of substitution by flaxseed on chemical composition of the best sensory evaluation sample of bread, pizza and Tahina products.

\begin{tabular}{|c|c|c|c|c|c|}
\hline \multirow[b]{2}{*}{ Samples } & \multicolumn{5}{|c|}{ chemical composition } \\
\hline & Protein & Fat & $\begin{array}{l}\text { Crude } \\
\text { fiber }\end{array}$ & Ash & $\begin{array}{c}\text { Total } \\
\text { carbohydrates }\end{array}$ \\
\hline \multicolumn{6}{|l|}{ Bread } \\
\hline Control & $13.65 \pm 1.03^{b}$ & $3.51 \pm 0.46^{\mathrm{b}}$ & $3.14 \pm 0.18^{\mathrm{a}}$ & $1.31 \pm 0.31^{\mathrm{b}}$ & $78.39 \pm 3.86^{\mathrm{a}}$ \\
\hline Substitute $15 \%$ & $15.59 \pm 1.36^{\mathrm{a}}$ & $4.37 \pm 0.39^{a}$ & $3.96 \pm 0.20^{\mathrm{a}}$ & $1.62 \pm 0.25^{\mathrm{a}}$ & $74.46 \pm 3.41^{\mathrm{b}}$ \\
\hline \multicolumn{6}{|l|}{ Pizza } \\
\hline Control & $14.0 \pm 1.56^{\mathrm{a}}$ & $10.1 \pm 1.00^{\mathrm{a}}$ & $2.5 \pm 0.08^{b}$ & $2.8 \pm 0.17^{b}$ & $70.6 \pm 2.05^{a}$ \\
\hline Substitute $15 \%$ & $15.3 \pm 0.98^{\mathrm{a}}$ & $11.0 \pm 0.95^{\mathrm{a}}$ & $2.9 \pm 0.10^{\mathrm{a}}$ & $3.1 \pm 0.21^{\mathrm{a}}$ & $67.7 \pm 2.42^{b}$ \\
\hline \multicolumn{6}{|l|}{ Tahina } \\
\hline Control & $24.2 \pm 1.87^{b}$ & $58.0 \pm 3.14^{\mathrm{a}}$ & $3.7 \pm 0.23^{b}$ & $3.1 \pm 0.25^{\mathrm{a}}$ & $11.0 \pm 1.53^{b}$ \\
\hline Substitute $50 \%$ & $26.1 \pm 1.54^{\mathrm{a}}$ & $54.1 \pm 2.86^{\mathrm{a}}$ & $4.1 \pm 0.11^{\mathrm{a}}$ & $2.5 \pm 0.19^{b}$ & $13.2 \pm 1.87^{\mathrm{a}}$ \\
\hline
\end{tabular}

\subsection{Biological evaluation of products}

\subsubsection{Effect of different products on lipids profile}

The effect of different experimental products containing dried bread, (DB), dried bread $15 \%$ flaxseed, (DBF), dried pizza, (DP), dried pizza 15\% flaxseed, (DPF), Tahina, (T) and Tahina 50\% flaxseed (TF), on serum total cholesterol (TC), total lipids (TL) and triglycerides of hypercholesterolemic rats are shown in table (7). Feeding rats on hypercholesteromic diet for 28 days induced a significant increase $(p<0.05)$ in cholesterol levels. Feeding on experimental diets significantly decreased serum total cholesterol as compared to the positive control group. The diet containing dried bread DBF and dried pizza DPF containing 15\% flaxseed decreased the level of TC more than the diets containing control dried bread and dried pizza groups. While, the hypercholesterolemic rats fed on Tahina $50 \%$ flaxseed led to significant differences in total cholesterol as compared to the hypercholesterolemic experimental diet. Yamashita et al., (2003) reported that, the flaxseed oil lowered plasma total cholesterol than defatted flaxseed and sesame seed. Generally, the diets containing flaxseed were more affecting on the concentration of serum total cholesterol than the same diet with no flaxseed.

Whole flaxseed contains approximately $40 \%$ fat. It is particularly rich in alphalinolenic acid (about $57 \%$ of the total fatty acid) which has lipid-lowering properties. Thus, the reduction of blood cholesterol by different products containing flaxseed in these studies may be due in part to alpha-linolenic acid present in the seeds. 
Bierenbaum et al., (1993) found that flaxseed supplementation in the form of either a flaxseed containing bread or $15 \mathrm{~g}$ of ground flaxseed resulted in significant reductions in serum total cholesterol in human subjects with hyperlipidemia. Also, Bhathena et al., (2002) found that total plasma cholesterol was lower by $41 \%(p<0.05)$ in rats fed flaxseed meal and by $15 \%$ in rats fed soy protein.

Regarding the total lipids and triglyceride of serum for different groups of rats, results in the same table showed that, the total lipids of rats fed hypercholesterolemic diet was in high score $(419.35 \pm 6.89 \mathrm{mg} / \mathrm{dl})$ and was significantly higher than in case of other groups of rats. On the contrary, rats fed on diets (DBF, DPF and TF) containing flaxseed were less in TL and TG than other groups fed on diets without flaxseed and showed significant difference. This low level of serum total lipids for three groups indicates about the effect of flaxseed as lowering lipid in rats blood. Furthermore, Tahina (sesame) exhibited the same manner in lowering lipid of rat serum, but was less effective compared with Tahina $50 \%$ flaxseed.

In this connection, the triglyceride of rat serum was scoped in the same way as total lipids which was at high concentration for hypercholesterolemic group, at low concentration for groups fed diets containing flaxseed (DBF, DPF and TF) and was in moderate state for the other groups. However, values were at very low concentrations for the normal rat which fed on basel diet. These data agree well with that of Bhathena et al., (2002) who found that, the diet content $20 \%$ flaxseed significantly reduced triglyceride level in F 344 rats with normal lipid levels as well as in obese SHR/N-CP rats with marked hyperlipidemia. Gaafar (2005) reported that hypercholesterolemic rats fed diet containing cakes fortified with hulled flaxseed showed a significant reduction in triglyceride level.

Table 7. Effect of different diets on total cholesterol (TC), total lipids (TL) and triglycerids (TG) of hypercholesterolemic rats ( $n=6$ rats).

\begin{tabular}{|l|c|c|c|}
\hline \multirow{2}{*}{ Groups } & \multicolumn{3}{c|}{ Parameters (mg / dl) } \\
\cline { 2 - 4 } & TC & TL & TG \\
\hline Control (-ve) & $89.71^{\mathrm{f}} \pm 2.56$ & $265.46^{\mathrm{e}} \pm 8.53$ & $93.05^{\mathrm{f}} \pm 3.15$ \\
\hline Hypercholesterolemic (+ve) & $160.44^{\mathrm{a}} \pm 4.08$ & $419.35^{\mathrm{a}} \pm 6.89$ & $184.80^{\mathrm{a}} \pm 4.97$ \\
\hline Dried bread ( DB ) & $139.65^{\mathrm{b}} \pm 3.64$ & $397.56^{\mathrm{b}} \pm 4.04$ & $132.67^{\mathrm{b}} \pm 4.35$ \\
\hline Dried bread+15\% flaxseed (DBF) & $123.52^{\mathrm{c}} \pm 3.82$ & $387.40^{\mathrm{bc}} \pm 5.52$ & $124.52^{\mathrm{c}} \pm 4.28$ \\
\hline Dried pizza ( DP ) & $142.24^{\mathrm{b}} \pm 4.05$ & $396.17^{\mathrm{b}} \pm 4.15$ & $136.54^{\mathrm{b}} \pm 4.09$ \\
\hline Dried pizza+15\% flaxseed ( DPF ) & $115.16^{\mathrm{d}} \pm 2.96$ & $367.19^{\mathrm{c}} \pm 4.54$ & $115.64^{\mathrm{d}} \pm 3.98$ \\
\hline Tahina sesame ( T ) & $127.59^{\mathrm{c}} \pm 3.17$ & $298.54^{\mathrm{d}} \pm 2.76$ & $113.65^{\mathrm{d}} \pm 4.12$ \\
\hline Tahina 50\% flaxseed ( TF ) & $106.94^{\mathrm{e}} \pm 2.78$ & $271.82^{\mathrm{e}} \pm 4.97$ & $105.80^{\mathrm{e}} \pm 3.85$ \\
\hline
\end{tabular}

Means in the same column with different letters are significantly different $(P \leq 0.05)$. 


\subsubsection{Effect of different products on Lipoprotein cholesterol fractions}

The effect of different experimental diets containing dried bread, (DB), dried bread $15 \%$ flaxseed, (DBF), dried pizza, (DP), dried pizza $15 \%$ flaxseed, (DPF), Tahina, ( $\mathrm{T}$ ) and Tahina 50\% flaxseed (TF), on serum lipoprotein fractions (HDL, LDL and VLDL) of hypercholesterolemic rats are shown in table (7). HDL concentrations were significantly increased $(p<0.05)$ in the serum of rats fed all experimental diet except diet containing dried pizza control as compared to the hypercholesterolemic control group (increase was insignificant). On the other hand, all tested diets resulted in significant decrease $(p<0.05)$ as compared to the negative control except the hypercholesterolemic rats fed diet containing Tahina $50 \%$ flaxseed as it was 53.84 $\pm 3.13 \mathrm{mg} / \mathrm{dl}$.

These data may be due to the level of flaxseed in Tahina content. Flaxseed is rich source of lignans, with potential weak estrogenic and antiestrogenic activity similar to that of the isoflavones found in soy. If lignans block androgen or progesterone receptors, they may alter the cardiovascular disease risk profile by changing HDL-cholesterol metabolism (Thompson, 1998). On the other hand, Bierenbaum et al., (1993) showed no change in HDL cholesterol in human subject with hyperlipidemia when fed on bread containing flaxseed.

Table 8. Effect of different diets on lipoprotein fractions of hypercholesterolemic rats $(n=6$ rats $)$.

\begin{tabular}{|l|c|c|c|}
\hline \multirow{2}{*}{ Groups } & \multicolumn{3}{|c|}{ Parameters (mg / dl) } \\
\cline { 2 - 4 } & HDL-C & LDL-C & VLDL-C \\
\hline Control (-ve) & $54.73 \mathrm{a} \pm 3.25$ & $16.37^{\mathrm{f}} \pm 1.08$ & $18.61^{\mathrm{d}} \pm 1.37$ \\
\hline Hypercholesterolemic (+ve) & $42.27^{\mathrm{c}} \pm 2.98$ & $86.45^{\mathrm{a}} \pm 2.56$ & $36.96^{\mathrm{a}} \pm 1.96$ \\
\hline Dried bread (DB ) & $46.38^{\mathrm{b}} \pm 3.04$ & $70.85^{\mathrm{b}} \pm 3.14$ & $26.53^{\mathrm{b}} \pm 1.70$ \\
\hline Dried bread+15\% flaxseed ( DBF ) & $39.12^{\mathrm{d}} \pm 2.71$ & $52.24^{\mathrm{d}} \pm 3.06$ & $24.90^{\mathrm{bc}} \pm 1.90$ \\
\hline Dried pizza ( DP ) & $45.19^{\mathrm{b}} \pm 2.97$ & $75.81^{\mathrm{b}} \pm 2.97$ & $27.31^{\mathrm{b}} \pm 2.03$ \\
\hline Dried pizza+15\% flaxseed (DPF) & $53.84^{\mathrm{b}} \pm 3.13$ & $46.84^{\mathrm{e}} \pm 2.05$ & $23.13^{\mathrm{bc}} \pm 1.85$ \\
\hline Tahina sesame ( T ) & $56.84^{\mathrm{a}} \pm 3.13$ & $51.02^{\mathrm{c}} \pm 2.96$ & $22.73^{\mathrm{c}} \pm 1.76$ \\
\hline Tahina 50\% flaxseed (TF ) & $37.03^{\mathrm{d}} \pm 2.64$ & $28.94^{\mathrm{f}} \pm 2.15$ & $21.16^{\mathrm{c}} \pm 1.54$ \\
\hline
\end{tabular}

Means in the same column with different letters are significantly different $(P \leq 0.05)$.

Concerning $L D L$, the concentration was $16.37 \pm 1.08 \mathrm{mg} / \mathrm{dl}$ for the normal rats and $86.45 \pm 2.56 \mathrm{mg} / \mathrm{dl}$ for the positive control group. Feeding experimental diets significantly decreased the concentration of $L D L$ as compared to the hypercholesterolemic rat group. It is clear that, LDL concentration of hypercholesterolemic rat fed on dried pizza containing $15 \%$ flaxseed was lower than 
group rat fed on dried bread containing $15 \%$ flaxseed, its may be due to the higher feed intake. It could be noticed that serum LDLcholesterol for rats fed on Tahina 50\% flaxseed diet $(28.94 \pm 2.15 \mathrm{mg} / \mathrm{dl})$ was significantly decreased as compared to hypercholesterolemic rat fed on control Tahina (51.02 $\pm 2.96 \mathrm{mg} / \mathrm{dl})$ and significantly increased when compared to the negative control group. The components of flaxseed to which health benefits have been ascribed as LDL lowering, include its high contents of lignans and vegetable protein, (Jenkins et al., 1999). These authors showed that, the defatted flaxseed reduced serum concentration of LDL cholesterol due to alinolenic acid and soluble fiber, which may possess the mentioned effect. Generally, these data agree with those obtained by Gaafar (2005) who found that, LDL cholesterol decreased when hypercholesterolemic rats fed on cake content flaxseed.

Feeding hypercholesterolemic groups on experimental diets caused significant decreases $(p<0.05)$ in VLDL concentration, compared to control positive. The highest decrease VLDL was reported for the group of rats fed on diet containing Tahina control and Tahina 50\% flaxseed. Serum very low-density lipoprotein was calculated as $T G / 5$, so the decrease of triglyceride led to reduced concentration of VLDL. Bhathena et al., (2002) reported that plasma triglyceride was reduced by $37 \%$ in rats fed flaxseed meal and by $19 \%$ in rats fed soy protein.

\section{REFERENCES}

1. A.O.A.C. 2000. Official Methods of Analysis of the Association of Official Analytical Chemists, 17th Ed, Published by the Association of Official Analytical Chemists, USA.

2. Afaik, K. and A. Munir. 2007. Effect of flaxseed and wheat flour blends on dough rheology and bread quality. Journal of the Science of Food and Agriculture, 87 (6): 1172.1173.

3. Allain, C.Z. and L. S. Poon. 1974. Enzymatic determination in total serum cholesterol. Clin. Chem, 20: 470 . 475.

4. Arafat, S. M., Amany M. M. Basuny and Dalia. Mostafa, M. 2008. Production of Tahina substitute from flaxseed (Linum usitatissimum). J. Biol. Chem. Environ. Sci., 3 (1): 681 . 696.

5. Bhathena, S. J., A. A. Ali, I. M. Ali, T. H. Carl and T. V. Manuel. 2002. Differential effects of dietary flaxseed protein and soy protein on plasma triglyceride and uric acid levels in animal models. J. of Nutr. Biochem., 13: 684 . 689. 
6. Bierenbaum, M. L., R. Reichstein and T. R. Watkins. 1993. Reducing atherogenic risk in hyperlipidemic humans with flaxseed supplementation: A preliminary report. J. Am. Coll. Nutr., 12: 501 . 504.

7. Burstein, M. 1970 . HDL cholesterol determination after separation high density lipoprotein. Lipid Res., 11: 583.

8. Campbell, J. A. 1963. Methodology of Protein Evaluation RAG Nutr., Document R. 10L Ed., 37. June Meeting New York.

9. Chalvardjian, A. M. 1964. Fatty acids of brown and yellow fat in rats. Biochem. J. 90: 518.

10. El-Kady, Eman A. A. 1995. Chemical and Technological Studies on Some Seed Oils. M.Sc. Thesis, Fac. of Agric., Kafr El-Sheikh, Tanta Univ.

11. Fredrickson, D.S., R.I. Levy and R.S. Lees. 1967. Fat transport in lipoprotein. an integrated approach to mechanisms and disorders. New Engl. J. Med., 276 (1): 34 -42 .

12. Gaafar, A. M. 2005. Production and evaluation of cake fortified by flaxseed as a functional food. Minufiya J. Agric. Res., 30: 1741 . 1756.

13. Harper, R. C., Edwards and A. T. Jacobson. 2006. Flaxseed oil supplementation does not affect plasma lipoprotein concentration or particle size in human subjects. J. of Nutrition, 136 (11): 2844 . 48.

14. Jenkins, D.J.A., C.W. Kendall, E. Vidgen, S. Agarwal, A.V. Rao, R.S. Rosenberg, L.C., Cunnane, S.C., 1999. Health aspects of partially defatted flaxseed, including effects on serum lipids, oxidative measures, and ex vivo androgen and progestin activity: a controlled crossover trial. American Journal of Clinical Nutrition 69, 395402.

15. Lee, R. and D. Nieman. 1996. Nutrition Assessment. 2nd Ed. Missouri, USA.

16. Montesano, M., M. W. Duffrin and K. Heidal. 2002. Consumer acceptance of pizza and pizza crust made with whole wheat flour and added flaxseed. Journal of the American Dietetic Association, A-55. Nutr., 69: 395 . 402.

17. Pohjanheimo, Terhi A., Mari A. Hakala, Raija L. Tahvonen, Seppo J. Salminen and Heikki P. Kallio. 2006. Flaxseed in breadmaking: Effects on sensory quality, aging and composition of bakery products. Journal of Food Science, 71 (1): S 343 . S 348.

18. Saba, Nargis H. 1991. Cooking, Science and Art, Dar El-Maarif, Pub. Egypt (In Arabic), 4th Edition. 
19. Snedecor, G. W. and W. C. Cocheran. 1980. Statistical Methods. 6 Ed., Iowa State University, Press.

20. Sylvie Dodin, M.D., C. Stephen Ph.D. Cunnane. 2008. Flaxseed on cardiovascular disease markers in healthy menopausal women: a randomized, double-blind, placebo-controlled trial. Nutrition 24 23-30

21. Thompson, L.U., S.E. Rickard, L.J. Orcheson, M.M. Seidl. 1996. Flaxseed and its lignan and oil components reduce mammary tumor growth at a late stage of carcinogenesis. Carcinogenesis 17, 1373-1376.

22. Toro, G. and P. G. Ackerman. 1975. Practical Clinical Chemistry. 1st Edition, Printed by Little, Brown and Company, Boston USA, pp. 352 . 355.

23. Yamashita, K., S. Ikeda and M. Obavashi. 2003. Comparative effects of flaxseed and sesame seed on vitamin E and cholesterol levels in rats. Lipids, 38: 1249 . 1255. 
الخواص الحسية و الكيميائية والبيولوجية لبعض المنتجات المدعمة

ببذور الكتان الكاملة

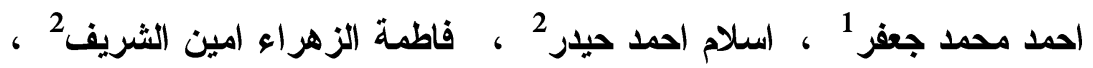
سمير محمد الاشلوطى2 2

ا ـ قسم الاغنية الخاصة والتغنية- معطه بحوث تكنولوجيا الأغنية - مركز البحوث الزراعية r r قسم التغذية وعلوم الاطعة - كلية الاقتصاد المنزلى - جامعة المنوفية

الغرض من هذه الدراسة هو تنمية وتدعيم بعض المنتجات الغذائية ببذور الكتان و واختبار القبول لدى المستهلكين كذلك تقييم تلك المنتجات كيميائيا وبيولو جيا. اظهر التركيب الكيميائي لللذور

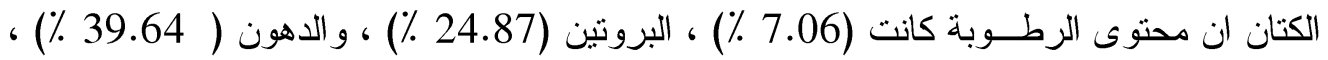

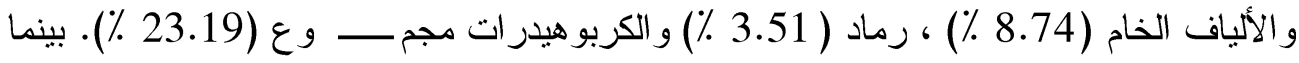
يحتوى زيت بذور الكتان على نسبة عالية من الاحماض الدهنية غير المشبعة حمض الأوليك (17.11 \%) ، وحمض اللينوليك (15.56 \%) وحمض اللينولينيك ( 58.68 \%). الظهر التقيبيم

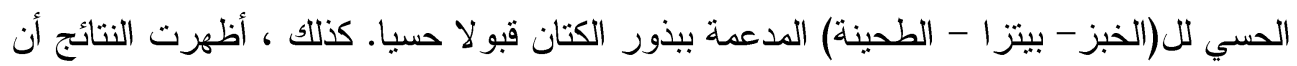
إضافة بذور الكتان إلى دقيق القمح بنسبة 15 ٪ ادى الى زيادة محتوى البروتين و الدهون و الألياف

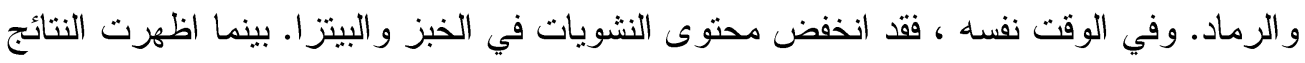

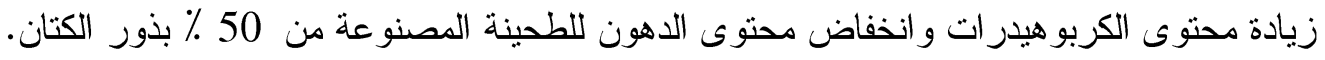

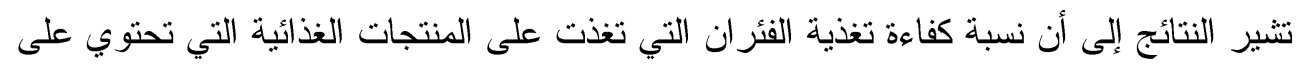

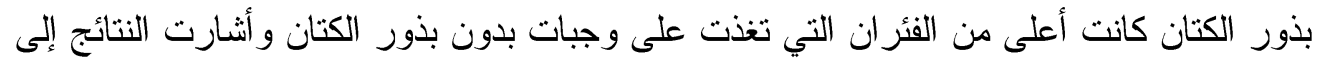

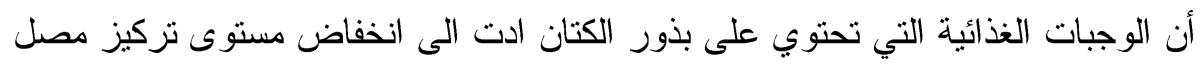

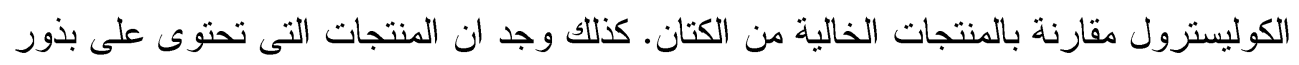

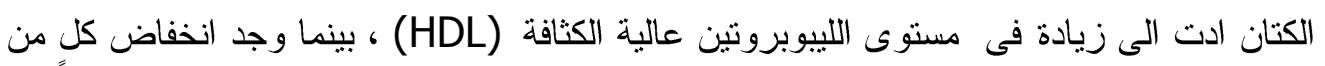
اللييوبروتين منخفضة الكثافة (LDL) و الليبوبروتين منخفضة الكثافة جدا (VLDL). 